\title{
Synthesis and structural characterization of dialkyltin complexes of $\boldsymbol{N}$-salicylidene-L-valine
}

https://doi.org/10.1515/mgmc-2020-0017

Received May 05, 2020; accepted July 21, 2020.

Abstract: The synthesis and characterization of five new chiral dialkyltin complexes of $N$-salicylidene- $L$-valine, $\left[2-\mathrm{O}-3-\mathrm{R}-5-\mathrm{R}^{\prime} \mathrm{C}_{6} \mathrm{H}_{2} \mathrm{C}(\mathrm{H})=\mathrm{NCH}\left(\mathrm{CH}\left(\mathrm{CH}_{3}\right)_{2}\right) \mathrm{C}(\mathrm{O}) \mathrm{O}\right] \mathrm{SnR}^{\prime \prime}{ }_{2}\left(\mathrm{R}, \mathrm{R}^{\prime}\right.$, $\mathrm{R}^{\prime \prime}=\mathrm{H}, \mathrm{H}, \mathrm{Me}(\mathbf{1}) ; \mathrm{H}, \mathrm{Br}, \mathrm{Me}(\mathbf{2})$; OMe, H, Et (3); Br, Br, $n$-Bu (4); $\mathrm{CH}(\mathrm{OMe})_{2}$, Me, $n$-Bu (5)), have been reported. Compounds 1-5 are all (S)-enantiomers, and their crystal structures have been studied. Compound 1 displays a trimeric macrocyclic structure in which the coordination environment of each tin atom is a distorted $\left[\mathrm{SnC}_{2} \mathrm{NO}_{3}\right]$ octahedron. In complexes 2-5, the tin atom has an intermediate geometry between trigonal bipyramidal and square pyramidal, and $\mathbf{3}$ is closer to a square pyramid. In crystals, a zigzag supramolecular chain is formed by the intermolecular C-H...O, O-H... or Sn ... O interactions.

Keywords: organotin; dialkyltin complex; $N$-salicylidene$L$-valine; crystal structure

\section{Introduction}

$L$-Valine is one of the 20 amino acids that make up protein, and is also essential amino acid and glycogen amino acid for mammalian. $N$-Salicylidene- $L$-valine derived from $L$-valine and salicylaldehyde, a chiral Schiff base carboxylate ligand, has excellent coordination ability and various coordination modes to metal ions. The structures and properties of metal complexes with this ligand have been extensively studied (Belokon et al., 2009; Chen et al., 2004, 2007; Ucar et al., 2017; Yu et al., 2015). These chiral metal complexes have been used as catalysts of the

\footnotetext{
${ }^{*}$ Corresponding author: Laijin Tian, Key Laboratory of Natural Products and Pharmaceutical Intermediates, Qufu Normal University, Qufu 273165, China; e-mail: laijintian@163.com Ruili Wang, Jiawei Zhang, Fubi Zhong and Yulin Qiu, Key Laboratory of Natural Products and Pharmaceutical Intermediates, Qufu Normal University, Qufu 273165, China
}

enantioselective reactions, as efficient reagents for DNA cleavage, and as chiral fluorescent molecular sensors. Organotin compounds have been widely used in organic synthesis, catalysis, materials, and medicinal/biocidal aspects (Davies et al., 2008). Organotin complexes with carboxylate ligands have attracted a lot of attention because they display higher catalytic and cytotoxic activity and the diversified structures (Arjmand et al., 2014; Bantia et al. 2019; Davies et al., 2008; Eng, 2017; Tian et al., 2019). Some organotin complexes of $N$-salicylidene- $L$ valine have been synthesized, and displayed good optical and biological properties (Beltran et al., 2003; Rivera et al., 2006; Tian et al., 2005, 2016, 2018; Yao et al. 2017). They are synthesized by treating the corresponding oxide or hydroxide with $N$-salicylidene- $L$-valine or from the reaction of the corresponding chloride with a sodium (or potassium) $\mathrm{N}$-salicylidene- $L$-valinate. Here, we report one-step synthesis and structural assignment of five new chiral dialkyltin complexes of $N$-salicylidene- $L$-valine derived from salicylaldehyde and $L$-valine, [2-O-3-R-5$\left.\mathrm{R}^{\prime} \mathrm{C}_{6} \mathrm{H}_{2} \mathrm{C}(\mathrm{H})=\mathrm{NCH}\left(\mathrm{CH}\left(\mathrm{CH}_{3}\right)_{2}\right) \mathrm{C}(\mathrm{O}) \mathrm{O}\right] \mathrm{SnR}^{\prime \prime}{ }_{2}\left(\mathrm{R}, \mathrm{R}^{\prime}, \mathrm{R}^{\prime \prime}=\mathrm{H}\right.$, $\mathrm{H}, \mathrm{Me}(\mathbf{1}) ; \mathrm{H}, \mathrm{Br}, \mathrm{Me}(\mathbf{2}) ; \mathrm{OMe}, \mathrm{H}$, Et (3); $\mathrm{Br}, \mathrm{Br}, n-\mathrm{Bu}$ (4); $\mathrm{CH}(\mathrm{OMe})_{2}$, Me, $n$-Bu (5)) (see Scheme 1).

\section{Results and discussion}

The title complexes 1-5 were obtained from the reaction of dialkyltin dichloride, salicylaldehyde, $L$-valine and DBU (1,8-diazabicyclo[5.4.0]undec-7-ene) in 1:1:1:2 molar ratios with the yields of $69-87 \%$ (see Scheme 1). In the reaction, the Schiff base ligand, DBUsalt $N$-salicylidene- $L$-valinate, was formed in situ. The rotation data of 1-5 showed that they have optical activity. The enantiomer was known to be $S$ configuration, which can be confirm by the crystal structures shown below. The method of one-pot reaction is simpler and more effective than the two-step method that requires isolation of the Schiff base carboxylate ligand (Baul et al., 2005, 2017; Tian et al., 2005). These yellow chiral complexes are air stable and can be further explored as potential chiral Lewis acid catalysts. 


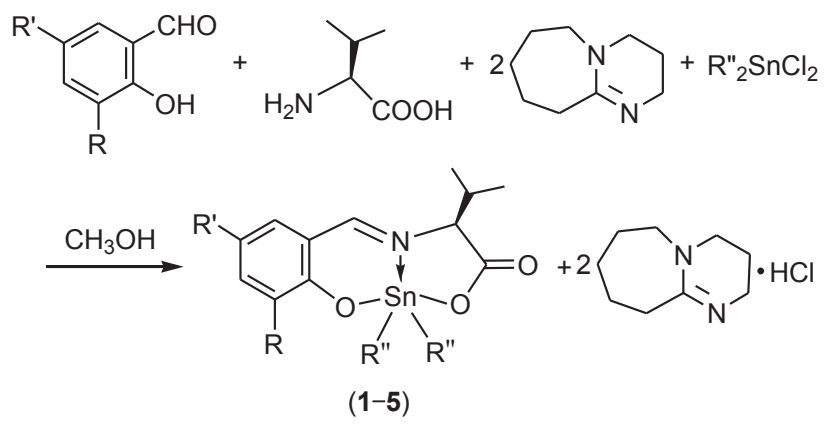

Scheme 1: Synthesis of complexes 1-5. R, R', R' = H, H, Me (1); H, Br, $\mathrm{Me}(2)$; OMe, $\mathrm{H}$, Et (3); $\mathrm{Br}, \mathrm{Br}, n-\mathrm{Bu}(4) ; \mathrm{CH}(\mathrm{OMe})_{2}$, Me, $n$ - $\mathrm{Bu}$ (5).

\subsection{Spectroscopic analysis}

Spectral identification of $\mathbf{1 - 5}$ is based on IR and NMR $\left({ }^{1} \mathrm{H},{ }^{13} \mathrm{C}\right.$ and $\left.{ }^{119} \mathrm{Sn}\right)$ experiments. In IR spectra of $\mathbf{1 - 5}$, the $v(\mathrm{C}=\mathrm{N})$ band appears in the range of $1609-1620 \mathrm{~cm}^{-1}$. Compared with the free Schiff bases $\left(-1640 \mathrm{~cm}^{-1}\right)$, this band shifts towards lower wave-number, confirming there is the coordination of $\mathrm{C}=\mathrm{N}$ to tin atom in the complexes (Beltran et al., 2003). In 2-5, the strong absorptions, occurring in the ranges of $1653-1672$ and $1344-1360 \mathrm{~cm}^{-1}$, are assigned to the asymmetric stretching vibration $\left[v(C(O) O)_{\text {asym }}\right]$ and symmetric stretching vibration $\left[v(C(O) O)_{\text {sym }}\right]$ of the carboxylate group, respectively. In 1 , the $v(C(O) O)_{\text {asym }}$ band moves to a low wave-number and appears at $1583 \mathrm{~cm}^{-1}$. The magnitude of $\Delta v(\mathrm{C}(\mathrm{O}) \mathrm{O})\left[\mathrm{v}(\mathrm{C}(\mathrm{O}) \mathrm{O})_{\mathrm{asym}}-\mathrm{v}(\mathrm{C}(\mathrm{O}) \mathrm{O})_{\text {sym }}\right]$ is usually used to judge the bonding mode of carboxylate to metal atom (Baul et al., 2017; Deacon and Phillips, 1980). For the bidentate carboxylate group, the $\Delta v(\mathrm{C}(\mathrm{O}) \mathrm{O})$ value is generally less than $200 \mathrm{~cm}^{-1}$, while the $\Delta v(C(O) 0)$ value of the monodentate carboxylate group is generally greater than $200 \mathrm{~cm}^{-1}$. The $\Delta v(C(0) 0)$ values of $\mathbf{1 - 5}$ are 190,315 , 293,327 , and $312 \mathrm{~cm}^{-1}$, respectively, indicating that in 1 the carboxylate is bidentate coordination to tin, and in 2-5 there is a monodentate carboxylate moiety.

The ${ }^{1} \mathrm{H}$ and ${ }^{13} \mathrm{C}$ chemical shift values of $1-5$ are consistent with the predicted structures. The azomethine proton $(\mathrm{CH}=\mathrm{N}, \mathrm{H}-7)$ resonance displays signal at 8.19-8.26 ppm as singlet with the ${ }^{3} J\left({ }^{119} \mathrm{Sn}^{-1} \mathrm{H}\right)$ of $44-52 \mathrm{~Hz}$. The chiral carbon proton (N-CH, H-8) exhibits a doublet with center at $3.85 \mathrm{ppm}$, and the coupling constant, ${ }^{3}\left({ }^{1{ }^{119}} \mathrm{Sn}^{-1} \mathrm{H}\right)$, lies in the rang of $35-40 \mathrm{~Hz}$. The appearance of ${ }^{119} \mathrm{Sn}^{-1} \mathrm{H}$ coupling proves that there is coordination of azomethine nitrogen to tin in solution for these complexes. The resonance signals of benzene ring protons in salicylidene appear in the range of 6.71-7.85 ppm. The signals of the carboxylate carbon (C-11), azomethine carbon (C-7), and chiral carbon (C-8) appear in the range of 172.45-173.24, 170.89-173.00, and $74.11-74.62 \mathrm{ppm}$, respectively. In complexes $\mathbf{1 - 5}$, the chiral carbon and two rigid chelate rings around tin make the two organic groups bound to tin atom $\left(\mathrm{R}_{2}{ }_{2} \mathrm{Sn}\right)$ have different chemical environments, and give rise to different signals (Baul et al., 2017; Singh et al., 2018; Tian et al., 2005). For example, in 1 the Sn-Me groups display two sets of ${ }^{1} \mathrm{H}$ and ${ }^{13} \mathrm{C}$ NMR signals, and appear at $0.60,0.97\left({ }^{1} \mathrm{H}\right)$ and $-0.28,1.76\left({ }^{13} \mathrm{C}\right) \mathrm{ppm}$, respectively.

The solution structures of organotin complexes can be characterized by the ${ }^{1}\left({ }^{119} \mathrm{Sn}^{-13} \mathrm{C}\right)$ coupling constant and the ${ }^{119} \mathrm{Sn}$ NMR chemical shift (Holecek et al., 1986; Lockhart and Manders, 1987). In dimethyltin complexes 1 and 2, the ${ }^{1} J\left({ }^{119} \mathrm{Sn}^{-13} \mathrm{C}\right)$ value is 653 and $645 \mathrm{~Hz}$, respectively. According to the Lockhart's equation, ${ }^{1}\left({ }^{119} \mathrm{Sn}^{-13} \mathrm{C}\right)=$ $10.7 \theta-778$ (Lockhart and Manders, 1987), the calculated values of the C-Sn-C angle $(\theta)$ are $133.7^{\circ}$ for $\mathbf{1}$ and $133.0^{\circ}$ for 2. For complexes 3, 4 and 5, the $\theta$ value calculated by the Holecek's equation, ${ }^{1} J\left({ }^{119} \mathrm{Sn}^{-13} \mathrm{C}\right)=9.99 \theta-746$ (Holecek et al., 1986), is $131.7,134.5$ and $133.9^{\circ}$, respectively, similar to that of the five-coordinated tin compound. In 1-5, the ${ }^{119}$ Sn NMR exhibits a singlet at $-158.6,-157.6,-184.7,-196.2$ and $-196.8 \mathrm{ppm}$, respectively, which is characteristic of five-coordinated dimethyltin, diethyltin and dibutyltin complexes (Beltran et al., 2003; Degaonkar et al., 1994; Holecek et al., 1986; Liu et al., 2016; Singh et al., 2018). The trimeric structure of $\mathbf{1}$, shown in the crystal structure (see below), has been dissociated into monomer in solution (Liu et al., 2016, 2019). The data of ${ }^{1} J\left({ }^{119} \mathrm{Sn}^{-13} \mathrm{C}\right.$ ) and ${ }^{119} \mathrm{Sn}$ NMR indicate that each of 1-5 is five-coordinated monomer and has a distorted trigonal bipyramid geometry in $\mathrm{CDCl}_{3}$ solution.

\subsection{Crystal structures}

The crystal structures of 1-5 with the atom numbering schemes are shown in Figures 1-5, and selected bond lengths and angles are given in Table 1. Compounds 1-5 are all (S)-enantiomers. 1 crystallizes in trigonal crystal system with a chiral $R 3_{2}$ space group, and 2-5 crystallize in orthorhombic crystal systems with the chiral $P 2_{1} 2_{1} 2_{1}$ space groups. The Flack parameters (Flack, 1983) of the final refinement for 1-5 are $-0.023(15), 0.030(11),-0.021(11)$, $0.018(10)$ and $-0.013(12)$, respectively. It shows that the configuration of enantiomerically pure amino acid remains unchanged during the reaction.

Compound $\mathbf{1}$ is a threefold symmetric trimer with bridging carboxylate groups (Figure 1). In each monomer (asymmetric unit), the doubly charged anion, $\left[2-\mathrm{OC}_{6} \mathrm{H}_{4} \mathrm{C}(\mathrm{H})=\mathrm{NCH}\left(\mathrm{CH}\left(\mathrm{CH}_{3}\right)_{2}\right) \mathrm{C}(\mathrm{O}) \mathrm{O}\right]^{2-}$, is coordinated as a tridentate ligand via the carboxylate oxygen $\mathrm{O}(1)$, the azomethine nitrogen $\mathrm{N}(1)$ and the phenolic oxygen $\mathrm{O}(3)$ 
(a)

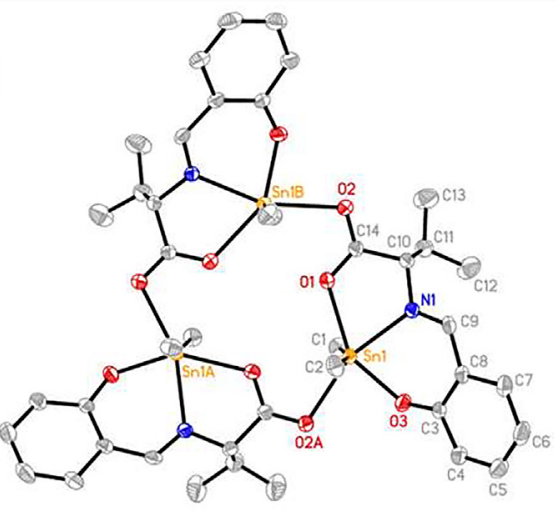

(b)

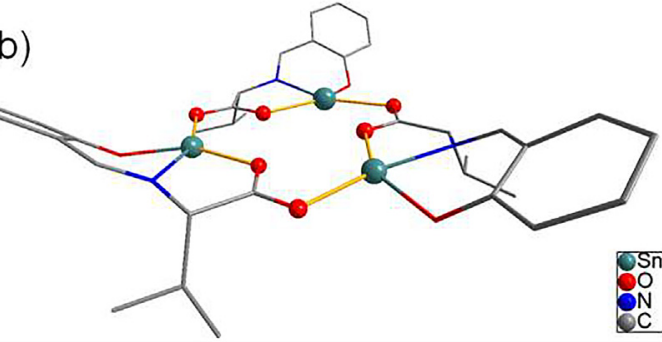

Figure 1: The molecular structure of 1. (a) Ellipsoid diagram ( $30 \%$ probability); (b) ball and stick diagram (methyls bound to tin are omitted for clarity).

(a)

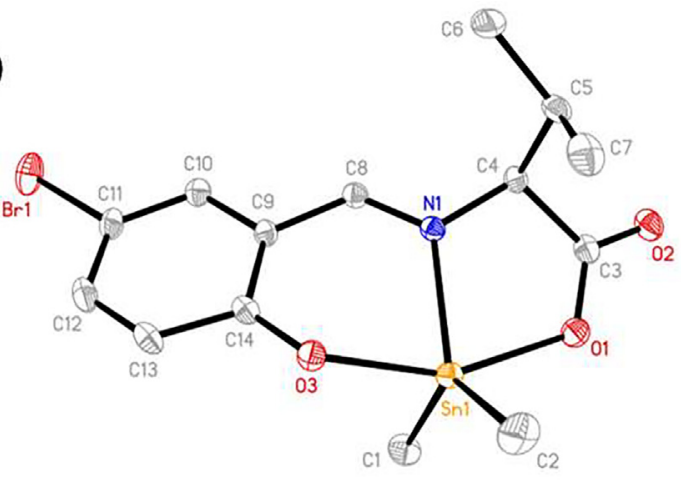

(b)

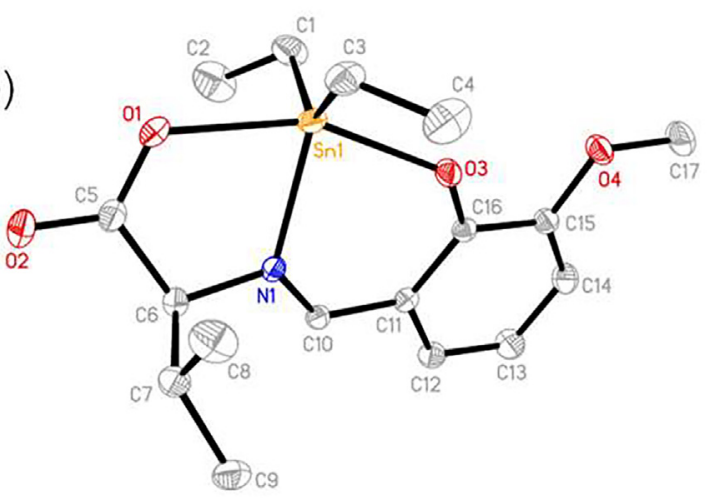

Figure 2: The molecular structures of $\mathbf{2}$ (a) and $\mathbf{3}$ (b). Ellipsoids are drawn at the $30 \%$ probability level. Hydrogen atoms are omitted for clarity. (a)

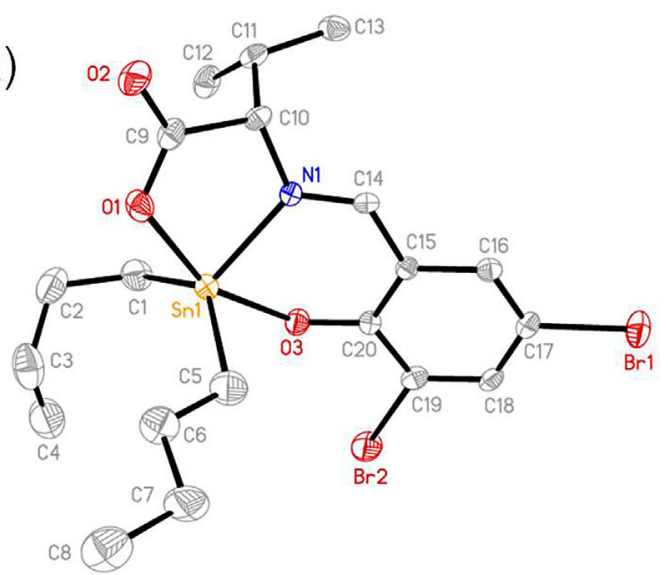

(b)

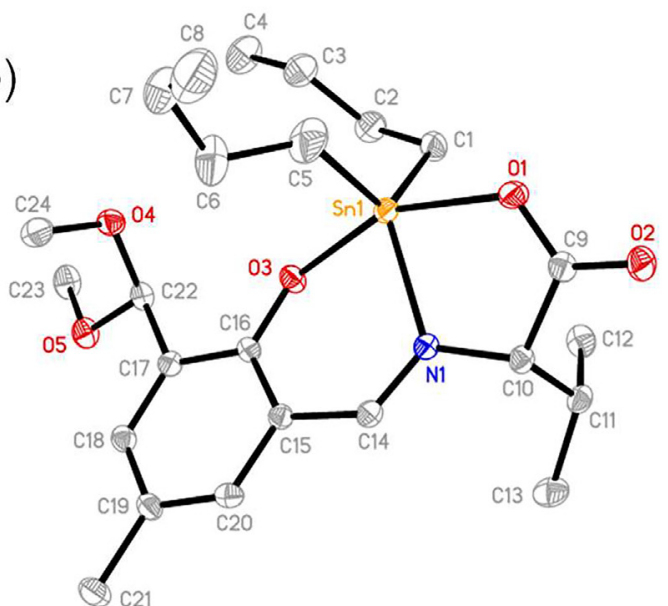

Figure 3: The molecular structures of 4 (a) and $\mathbf{5}$ (b). Ellipsoids are drawn at the $30 \%$ probability level. Hydrogen atoms are omitted for clarity.

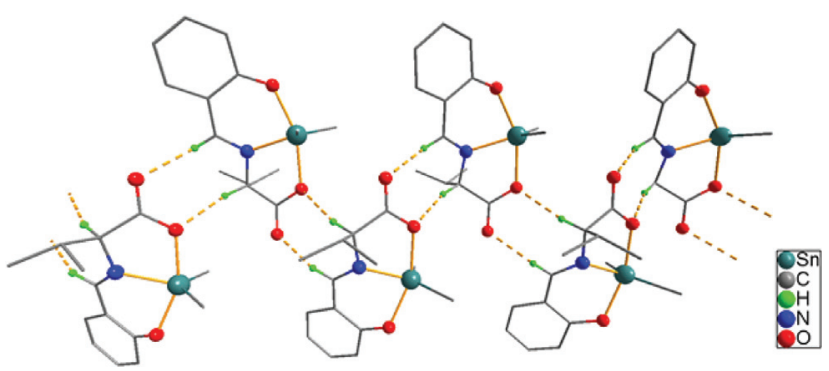

Figure 4: The 1D supramolecular chain in $\mathbf{2}$ and $\mathbf{5}$ formed by the intermolecular $\mathrm{C}-\mathrm{H} \ldots \mathrm{O}$ hydrogen bonds. Some $\mathrm{C}, \mathrm{H}$ and $\mathrm{O}$ atoms are not shown for clarity.

atoms. The trinuclear tin complx with a 12-membered $\left[\mathrm{Sn}_{3} \mathrm{O}_{6} \mathrm{C}_{3}\right]$ ring is formed by the bridges through the carbonyl oxygen $\mathrm{O}(2)$ atoms of the carboxylate $\mathrm{O}(1) \mathrm{C}(14)$ $\mathrm{O}(2)$ groups. In the bridging Sn-O-C-O-Sn moieties, the two Sn-O and two C-O bond lengths are 2.319(4)/2.386(4) $\AA$ and 1.264(7)/1.241(7) ̊, respectively. This asymmetric 


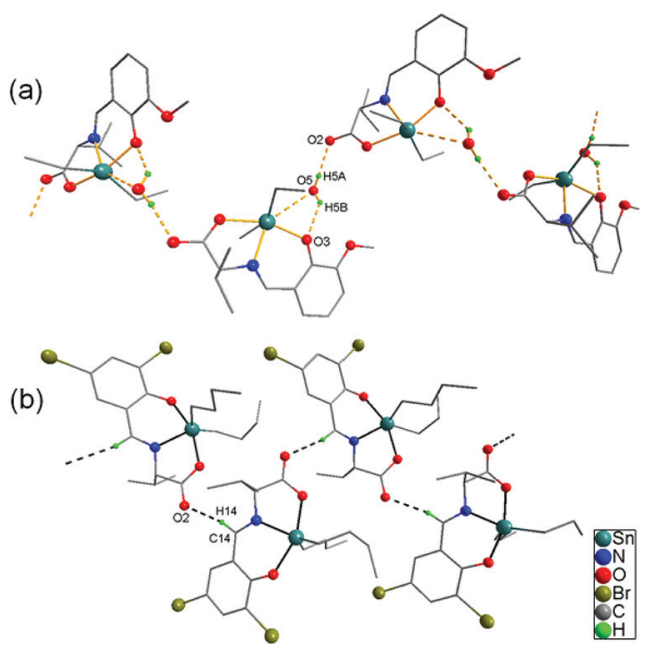

Figure 5: The 1D supramolecular chain in $3 \cdot \mathrm{H}_{2} \mathrm{O}$ (a) and 4 (b) formed by the intermolecular $\mathrm{O}-\mathrm{H} \ldots \mathrm{O}$ or $\mathrm{C}-\mathrm{H} \ldots \mathrm{O}$ hydrogen bonds. Hydrogen atoms are omitted for clarity.

bridging feature is also observed in other cyclic trinuclear organotin complexes with the Schiff base carboxylate ligands, such as $\left[n-\mathrm{Bu}_{2} \mathrm{Sn}\left(2-\mathrm{OC}_{6} \mathrm{H}_{4} \mathrm{C}(\mathrm{H})=\mathrm{NCH}_{2} \mathrm{C}(\mathrm{O}) \mathrm{O}\right)\right]_{3}(\mathrm{Baul}$ et al., 2005), $\left[\mathrm{Et}_{2} \mathrm{Sn}\left(2-\mathrm{OC}_{6} \mathrm{H}_{4} \mathrm{C}(\mathrm{H})=\mathrm{NCH}\left(\mathrm{CH}_{2} \mathrm{C}_{6} \mathrm{H}_{5}\right) \mathrm{C}(\mathrm{O}) \mathrm{O}\right)\right]_{3}$ (Liu et al., 2016), and $\left[\mathrm{Me}_{2} \mathrm{Sn}\left(2-\mathrm{OC}_{6} \mathrm{H}_{4} \mathrm{C}(\mathrm{H})=\mathrm{NCH}\left(\mathrm{CH}_{3}\right)\right.\right.$ $\mathrm{C}(\mathrm{O}) \mathrm{O})]_{3}$ (Singh et al., 2018). The coordination of the ONO tridentate ligand to tin atom leads to the formation of two chelate rings $\mathrm{Sn}(1) \mathrm{N}(1) \mathrm{C}(10) \mathrm{C}(14) \mathrm{O}(1)$ and $\mathrm{Sn}(1) \mathrm{O}(3) \mathrm{C}(3)$ $\mathrm{C}(8) \mathrm{C}(9) \mathrm{N}(1)$. The coordination sphere of the tin atom is a distorted octahedron with a $\mathrm{C}(1)-\mathrm{Sn}(1)-\mathrm{C}(2)$ angle of $158.1(3)^{\circ}$ in trans-position. The distortion from the ideal octahedron may be due to the rigid framework of the chelate rings and the weak interaction between $\operatorname{Sn}(1)$ atom and carboxylate $\mathrm{O}(1)^{\#}$ (symmetry code \#: $1-y, x-y, z$.) atom of a neighboring ligand $\left(\mathrm{Sn}(1) \ldots \mathrm{O}(1)^{\#} 2.920(5) \AA\right)$. The stereoscopic effect of $\mathrm{Sn}(1) \ldots \mathrm{O}(1)^{\#}$ action expands the bond angle $\mathrm{O}(1)-\mathrm{Sn}(1)-\mathrm{O}(2)^{\#}$ to $130.33(15)^{\circ}$ and reduces the bond angle $\mathrm{O}(3)-\mathrm{Sn}(1)-\mathrm{O}(2)^{\#}$ to $81.55(15)^{\circ}$.

The tin, oxygen and carbon atoms in the macrocycle $\left[(\mathrm{Sn}-\mathrm{O}-\mathrm{C}-\mathrm{O})_{3}\right]$ are almost in the same plane, and the largest deviation from the mean plane defined by the twelve atoms is only 0.004(4) $\AA$ (at O(1) atom). Three tin atoms are arranged in a regular triangle with the $\mathrm{Sn}$...Sn distance of 5.137(4) A. The three salicylidenes and three iso-propyls lie on opposite sides of the macrocycle plane. The dihedral angle between the planes of macrocycle and salicylidene is $140.27(3)^{\circ}$. The whole structure looks like the shape of a bowl (see Figure $1 b$ ).

Compounds 2-5 are all mononuclear tin complexes, and have similar discrete molecular structures (see Figures 2 and 3). In 2-5, the $N$-salicylidene- $L$-valinate ligand is bonded to tin atom by the carboxylate $\mathrm{O}(1)$ and phenolic $\mathrm{O}(3)$ atoms, and two covalent $\mathrm{Sn}-\mathrm{O}$ bonds, $\mathrm{Sn}(1)-\mathrm{O}(1)$ and $\mathrm{Sn}(1)-\mathrm{O}(3)$, are formed. The $\mathrm{Sn}(1)-\mathrm{O}(1)$ and $\mathrm{Sn}(1)$ $\mathrm{O}(3)$ bond lengths are in the ranges of 2.124(8)-2.180(3) and 2.086(4)-2.120(7) A, respectively. The coordination of imine $\mathrm{N}(1)$ atom to $\mathrm{Sn}(1)$ atom results in the generation of a five-membered and a six-membered chelate rings with a Sn(1)-N(1) bond of 2.159(5)-2.180(3) Å. For five-coordinated metal centers, the Addison parameter $\tau$ is used to describe the distortion of the coordination geometry and is defined as $\tau=(\beta-\alpha) / 60$, where $\beta$ and $\alpha$ are the two largest angles around the central atom (Addison et al., 1984). In 2-5, the $1^{\text {st }}$ largest basal angle $\beta, O(1)-\mathrm{Sn}(1)-\mathrm{O}(3)$, is in the range of 155.05(18)-156.1(3) ${ }^{\circ}$. The $\tau$ values of $2-5$ are $0.49,0.32,0.40$ and 0.54 , respectively, indicating that the coordination geometry of tin atom in 2-5 is between trigonal bipyramidal ( $\tau=1.00)$ and square pyramidal $(\tau=0.00)$, and can be described as an intermediate geometry. However, $\mathbf{3}$ is closer to a square pyramid. The two $\mathrm{C}-\mathrm{O}$ lengths of the carboxylate in the complexes are obviously different, which further confirms the monodentate coordination mode of carboxylate group. For example, in 4, the distances of $\mathrm{C}(9)-\mathrm{O}(1)$ and $\mathrm{C}(9)-\mathrm{O}(2)$ bonds are 1.307(14) and 1.205(13) $\AA$, respectivly, showing the single and double bond characteristics of $\mathrm{C}-\mathrm{O}$ bonds. These features are also observed in other analogues, such as $n$ - $\mathrm{Bu}_{2} \mathrm{Sn}$ $\left(2-\mathrm{OC}_{6} \mathrm{H}_{4} \mathrm{C}(\mathrm{H})=\mathrm{NCH}\left(\mathrm{CH}\left(\mathrm{CH}_{3}\right)_{2}\right) \mathrm{C}(\mathrm{O}) \mathrm{O}\right)$ (Yin et al., 2004), $n-\mathrm{Bu}_{2} \mathrm{Sn}\left(3,5-\mathrm{Br}_{2}-2-\mathrm{OC}_{6} \mathrm{H}_{2} \mathrm{C}(\mathrm{H})=\mathrm{NCH}\left(\mathrm{CH}\left(\mathrm{CH}_{3}\right)_{2}\right) \mathrm{C}(\mathrm{O}) \mathrm{O}\right) \quad$ (Tian et al., 2007), and $\mathrm{Me}_{2} \mathrm{Sn}\left(5-\mathrm{Cl}-2-\mathrm{OC}_{6} \mathrm{H}_{3} \mathrm{C}(\mathrm{H})=\mathrm{NCH}\left(\mathrm{CH}\left(\mathrm{CH}_{3}\right)_{2}\right)\right.$ $\mathrm{C}(0) 0)$ (Tian et al., 2018).

In 2, 4 and 5, the molecules are connected through the intermolecular $\mathrm{C}-\mathrm{H} \ldots \mathrm{O}$ weak interactions between $\mathrm{H}$ atoms of azomethine or chairl carbon and $\mathrm{O}$ atoms of carboxylate group to give a zigzag supramolecular chain with the Sn...Sn dstance of 7.245(2), 8.286(2) and 7.781(2) $\AA$, respectively (see Table 2, Figures 4 and 5b). In the case of $\mathbf{3} \cdot \mathrm{H}_{2} \mathrm{O}$, a crystal water links two adjacent complexes via the hydrogen bonds $\mathrm{O}-\mathrm{H} \ldots \mathrm{O}=\mathrm{C}$ and $\mathrm{O}-\mathrm{H} \ldots \mathrm{O}-\mathrm{Ar}$ to generate a one-dimensional supramolecular chain (see Table 2, Figure 5a). The contact between $\mathrm{Sn}(1)$ and $\mathrm{O}(5)$ of the water is 3.135(5) $\AA$, and is clearly less than the sum of their Van der Waals radii (3.70 ̊). The $\operatorname{Sn}(1) \ldots O(5)$ acton in $\mathbf{3} \cdot \mathrm{H}_{2} \mathrm{O}$ is also one of the reasons for distorting the coordination geometry. The $\mathrm{C}-\mathrm{Sn}-\mathrm{C}$ bond angles of $\mathbf{2}, \mathbf{3} \cdot \mathrm{H}_{2} \mathrm{O}, \mathbf{4}$, and $\mathbf{5}$ are 126.3(3), 136.3(2), 132.2(7), and $120.4(6)^{\circ}$, respectively. Compared with the value calculated on the basis of NMR coupling constant in $\mathrm{CDCl}_{3}$, the $\mathrm{C}-\mathrm{Sn}-\mathrm{C}$ angle obtained from crystalline-state decreases for 2, 4 and 5, and increases for $\mathbf{3} \cdot \mathrm{H}_{2} \mathrm{O}$. The differences can be attributed to the absence of the aforementioned short contact in chloroform solution. Thus, the Lockhart 
Table 1: Selected bond lengths $(\AA)$ and angles $\left(^{\circ}\right)$ for the complexes*.

\begin{tabular}{|c|c|c|c|c|c|}
\hline & 1 & 2 & $3 \cdot \mathrm{H}_{2} \mathrm{O}$ & 4 & 5 \\
\hline $\operatorname{Sn}(1)-C(1)$ & $2.104(5)$ & $2.104(6)$ & $2.132(5)$ & $2.132(13)$ & $2.128(8)$ \\
\hline$S n(1)-C(n)$ & $2.110(5)$ & $2.101(6)$ & $2.116(4)$ & $2.129(14)$ & $2.041(11)$ \\
\hline $\operatorname{Sn}(1)-N(1)$ & $2.292(5)$ & $2.162(4)$ & $2.184(3)$ & $2.171(8)$ & $2.159(5)$ \\
\hline $\operatorname{Sn}(1)-O(1)$ & $2.319(4)$ & $2.146(4)$ & $2.180(3)$ & $2.124(8)$ & $2.145(5)$ \\
\hline $\operatorname{Sn}(1)-O(2)^{\#}$ & $2.386(4)$ & - & - & - & - \\
\hline $\operatorname{Sn}(1)-0(3)$ & $2.093(4)$ & $2.101(4)$ & $2.092(3)$ & $2.120(7)$ & $2.086(4)$ \\
\hline$O(3)-S n(1)-C(1)$ & $102.8(2)$ & $96.3(2)$ & $97.5(2)$ & $90.6(4)$ & $93.5(3)$ \\
\hline$O(3)-S n(1)-C(n)$ & $94.4(2)$ & $94.1(2)$ & $96.20(16)$ & $89.9(5)$ & 101.2(5) \\
\hline$C(1)-S n(1)-C(n)$ & 158.1(3) & 126.3(3) & $136.3(2)$ & $132.2(7)$ & $120.4(6)$ \\
\hline$O(3)-S n(1)-N(1)$ & $79.49(15)$ & $81.79(14)$ & $81.93(11)$ & 81.3(3) & 81.41(19) \\
\hline$C(1)-S n(1)-N(1)$ & $93.2(2)$ & $123.6(3)$ & $117.30(17)$ & $119.8(5)$ & $122.7(3)$ \\
\hline$C(n)-S n(1)-N(1)$ & $103.2(2)$ & $110.0(2)$ & 105.63(17) & 107.5(5) & $116.5(5)$ \\
\hline$O(3)-S n(1)-O(1)$ & $147.82(15)$ & $155.85(14)$ & $155.54(12)$ & 156.1(3) & $155.05(18)$ \\
\hline$C(1)-S n(1)-O(1)$ & $87.4(2)$ & $95.8(2)$ & $93.3(2)$ & $96.6(5)$ & $93.5(3)$ \\
\hline$C(n)-S n(1)-O(1)$ & $84.9(2)$ & $95.5(3)$ & $90.98(18)$ & 101.7(6) & $95.7(5)$ \\
\hline$N(1)-S n(1)-O(1)$ & $69.45(14)$ & 74.44(15) & $74.02(12)$ & 75.3(3) & $74.6(2)$ \\
\hline$N(1)-S n(1)-O(2)^{\#}$ & $159.41(15)$ & - & - & - & - \\
\hline
\end{tabular}

*For 1 and $2, \mathrm{n}=2$; for $3 \cdot \mathrm{H}_{2} \mathrm{O}, \mathrm{n}=3$; for 4 and $\mathbf{5}, \mathrm{n}=5$; " symmetry code: $1-y, x-y, z$.

Table 2: H-Bonding geometry parameters $\left(\AA{ }^{\circ}{ }^{\circ}\right)$ for the complexes.

\begin{tabular}{|c|c|c|c|c|c|c|}
\hline Compound & $D-H \cdots A$ & D-H (Å) & $H \cdots A(\AA)$ & D...A (Å) & $D-H \cdots A\left({ }^{\circ}\right)$ & Symmetry code ${ }^{\#}$ \\
\hline \multirow[t]{2}{*}{2} & $\mathrm{C}(4)-\mathrm{H}(4) \cdots \mathrm{O}(1)^{\#}$ & 0.98 & 2.30 & $3.2546(3)$ & 165 & $x-1 / 2,-y-1 / 2,-z$ \\
\hline & $\mathrm{C}(8)-\mathrm{H}(8) \ldots \mathrm{O}(2)^{\#}$ & 0.93 & 2.33 & $3.1595(3)$ & 148 & $x-1 / 2,-y-1 / 2,-z$ \\
\hline \multirow[t]{2}{*}{$3 \cdot \mathrm{H}_{2} \mathrm{O}$} & $\mathrm{O}(5)-\mathrm{H}(5 \mathrm{~A}) \ldots \mathrm{O}(2)^{\#}$ & 0.85 & 1.97 & $2.7761(3)$ & 159 & $-x, y-1 / 2,-z+1 / 2$ \\
\hline & $\mathrm{O}(5)-\mathrm{H}(5 \mathrm{~B}) \ldots \mathrm{O}(3)$ & 0.85 & 2.19 & $2.8719(3)$ & 138 & \\
\hline 4 & $\mathrm{C}(14)-\mathrm{H}(14) \cdots \mathrm{O}(2)^{\#}$ & 0.93 & 2.43 & $3.3434(6)$ & 166 & $-x, y+1 / 2,-z+1 / 2$ \\
\hline \multirow[t]{2}{*}{5} & $\mathrm{C}(10)-\mathrm{H}(10) \ldots \mathrm{O}(1)^{\#}$ & 0.98 & 2.43 & $3.3556(5)$ & 158 & $-x+1, y+1 / 2,-z+1 / 2$ \\
\hline & $\mathrm{C}(14)-\mathrm{H}(14) \ldots \mathrm{O}(2)^{\#}$ & 0.93 & 2.48 & $3.4048(5)$ & 173 & $-x+1, y+1 / 2,-z+1 / 2$ \\
\hline
\end{tabular}

(or Holecek) equation overestimates the $\mathrm{C}-\mathrm{Sn}-\mathrm{C}$ angle for 2, 4 and 5 but underestimates for $\mathbf{3} \cdot \mathrm{H}_{2} \mathrm{O}$.

\section{Conclusions}

Five chiral dialkyltin complexes of $N$-salicylidene- $L$-valine have been prepared by one-pot reaction in the presence of organic strong base DBU. In non-coordinated solvent, each complex is monomer containing a five-coordinated tin atom. In crystal state, complex 1 displays a trimeric structure with 12-membered macrocycle, and each tin atom possesses a distorted octahedron geometry. Complexes 2-5 are all mononuclear tin complexes and their tin atoms have the geometries between the trigonal bipyramid and square pyramid. These chiral complexes can be further explored as potential chiral Lewis acid catalysts.

\section{Experimental}

All chemicals were commercial grade and had not been further purified before use. Dialkyltin dichlorides $\left(\mathrm{Me}_{2} \mathrm{SnCl}_{2}, \mathrm{Et}_{2} \mathrm{SnCl}_{2}\right.$, and $\left.n-\mathrm{Bu}_{2} \mathrm{SnCl}_{2}\right)$ and 3-methoxysalicyaldehyde were purchased from Tianjin Heowns Biochemical Technology Company Limited (Tianjin, China), and other materials were from Energy Chemical Reagent Company Limited (Shanghai, China). Physical measurements including elecmental analyses and IR and NMR spectra were the same as our previous report (Yao et al., 2017). 


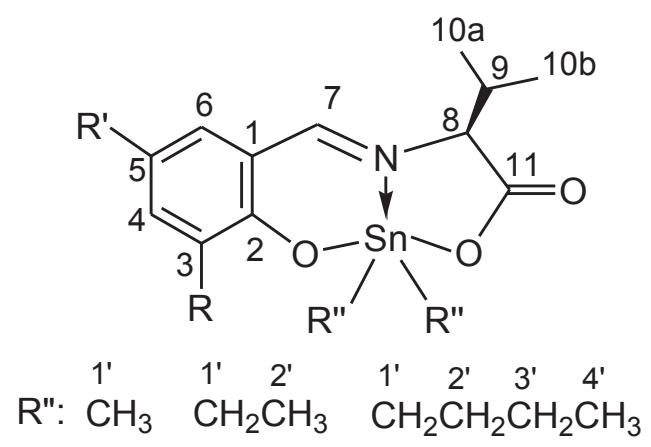

Scheme 2: Numbering scheme for NMR assignment.

\section{Preparation of 1-5}

Methanol (60 mL), L-valine (0.176 g, $1.5 \mathrm{mmol})$, salicylaldehyde (0.183 g, $1.5 \mathrm{mmol})$, dimethyltin dichloride (0.330 g, $1.5 \mathrm{mmol}$ ), and DBU (0.457 g, $3.0 \mathrm{mmol}$ ) were successively added to a $100 \mathrm{~mL}$ round bottom flask under electromagnetic stirring. The reaction mixtures were heated and refluxed stirring for $4 \mathrm{~h}$. The yellow solution obtained was evaporated under reduced pressure using a rotary evaporator. The remaining yellow residue is washed with water to remove the DBU hydrochloride, dried in vacuum at room temperature, and recrystallized from dichloromethane-methanol mixed solvent to give pure product of $\mathbf{1}$. Compounds 2-5 were prepared similarly. The numbering scheme for NMR assignment is as presented in Scheme 2.

\section{(S)- $\left[2-\mathrm{OC}_{6} \mathrm{H}_{4} \mathrm{C}(\mathrm{H})=\mathrm{NCH}\left(\mathrm{CH}\left(\mathrm{CH}_{3}\right)_{2}\right) \mathrm{C}(\mathrm{O}) \mathrm{O}\right] \mathrm{SnMe}_{2}(\mathbf{1})$}

Yield: $87 \%(0.48 \mathrm{~g})$. M.p.: $244-245^{\circ} \mathrm{C} .[\alpha]_{\mathrm{D}}^{23}(c=0.24$ $\left.\mathrm{g} \cdot \mathrm{mL}^{-1}, \mathrm{CH}_{2} \mathrm{Cl}_{2}\right)=-182.5^{\circ}$. Elemental analysis calcd for $\mathrm{C}_{14} \mathrm{H}_{19} \mathrm{NO}_{3} \mathrm{Sn}$ : C, 45.69; H, 5.20; N, 3.81\%. Found: C, 45.46; $\mathrm{H}, 5.08 ; \mathrm{N}, 3.77 \%$. IR ( $\mathrm{KBr}$ pellets, $\left.\mathrm{cm}^{-1}\right): 1620 \mathrm{v}(\mathrm{C}=\mathrm{N}), 1583$ $\mathrm{v}(\mathrm{C}(\mathrm{O}) \mathrm{O})_{\text {asym }}, 1393 \mathrm{v}(\mathrm{C}(\mathrm{O}) \mathrm{O})_{\text {sym }} \cdot{ }^{1} \mathrm{H} \mathrm{NMR}\left(\mathrm{CDCl}_{3}, \delta\right): 0.60$ (s, 3H, H-1'), 0.97 (s, 3H, H-1'), 1.06 (d, 3H, H-10a), 1.10 (d, $3 \mathrm{H}, \mathrm{H}-10 \mathrm{~b}), 2.35-2.41$ (m, 1H, H-9), $3.88\left(\mathrm{~d},{ }^{3} \mathrm{~J}\left({ }^{119} \mathrm{Sn}^{-1} \mathrm{H}\right)=38\right.$ $\mathrm{Hz}, 1 \mathrm{H}, \mathrm{H}-8), 6.79$ (t, 1H, H-5), 6.82 (d, 1H, H-3), 7.23 (d, 1H, $\mathrm{H}-6), 7.46$ (t, 1H, H-4), $\left.8.26\left(\mathrm{~s},{ }^{3} \mathrm{~J}^{(119} \mathrm{Sn}^{-1} \mathrm{H}\right)=52 \mathrm{~Hz}, 1 \mathrm{H}, \mathrm{H}-7\right)$. ${ }^{13} \mathrm{C}$ NMR ( $\left.\mathrm{CDCl}_{3}, \delta\right): 173.05$ (C-11), 173.00 (C-7), 168.95 (C-2), 137.85 (C-6), 135.72 (C-4), 122.72 (C-3), 117.35 (C-1), 117.22 (C-5), 74.11 (C-8), 34.44 (C-9), 19.01 (C-10a), 18.24 (C-10b), $1.76\left({ }^{1} J\left({ }^{119} \mathrm{Sn}^{-13} \mathrm{C}\right)=668 \mathrm{~Hz}, \mathrm{C}-1^{1}\right),-0.28\left({ }^{1} J\left({ }^{119} \mathrm{Sn}^{-13} \mathrm{C}\right)=638\right.$ $\left.\mathrm{Hz}, \mathrm{C}-1^{\prime}\right) .{ }^{119} \mathrm{Sn} \mathrm{NMR}\left(\mathrm{CDCl}_{3}, \delta\right):-158.6$.

\section{(S)- $\left[5-\mathrm{Br}-2-\mathrm{OC}_{6} \mathrm{H}_{3} \mathrm{C}(\mathrm{H})=\mathrm{NCH}\left(\mathrm{CH}\left(\mathrm{CH}_{3}\right)_{2}\right) \mathrm{C}(\mathrm{O}) \mathrm{O}\right] \mathrm{SnMe}_{2}(\mathbf{2})$}

Yield: $80 \%(0.54 \mathrm{~g})$. M.p.: $229-230^{\circ} \mathrm{C} .[\alpha]_{\mathrm{D}}{ }^{23}(c=0.17$ $\left.\mathrm{g} \cdot \mathrm{mL}^{-1}, \mathrm{CH}_{2} \mathrm{Cl}_{2}\right)=-196.6^{\circ}$. Elemental analysis calcd for $\mathrm{C}_{14} \mathrm{H}_{18} \mathrm{BrNO}_{3} \mathrm{Sn}$ : C, 37.62; H, 4.06; N, 3.13\%. Found: C, 37.69; $\mathrm{H}, 4.04 ; \mathrm{N}, 3.16 \%$. IR ( $\mathrm{KBr}$ pellets, $\left.\mathrm{cm}^{-1}\right): 1666 \mathrm{v}(\mathrm{C}(\mathrm{O}) \mathrm{O})_{\text {asym}}$,
$1618 v(\mathrm{C}=\mathrm{N}), 1351 \mathrm{v}(\mathrm{C}(\mathrm{O}) \mathrm{O})_{\mathrm{sym}} \cdot{ }^{1} \mathrm{H} \mathrm{NMR}\left(\mathrm{CDCl}_{3}, \delta\right): 0.60$ (s, 3H, H-1'), 0.98 (s, 3H, H-1'), 1.06 (d, 3H, H-10a), 1.09 (d, 3H, H-10b), 2.34-2.41 (m, 1H, H-9), $3.88\left(\mathrm{~d},{ }^{3} J\left({ }^{119} \mathrm{Sn}^{-1} \mathrm{H}\right)=\right.$ $40 \mathrm{~Hz}, 1 \mathrm{H}, \mathrm{H}-8), 6.73$ (d, 1H, H-3), 7.36 (d, 1H, H-6), 7.49 $(\mathrm{dd}, 1 \mathrm{H}, \mathrm{H}-4), 8.20\left(\mathrm{~s},{ }^{3} \mathrm{~J}\left({ }^{119} \mathrm{Sn}^{-1} \mathrm{H}\right)=48 \mathrm{~Hz}, 1 \mathrm{H}, \mathrm{H}-7\right) .{ }^{13} \mathrm{C}$ NMR $\left(\mathrm{CDCl}_{3}, \delta\right): 172.45$ (C-11), 171.56 (C-7), 168.05 (C-2), 140.36 (C-4), 136.76 (C-6), 124.84 (C-1), 118.30 (C-3), 108.58 (C-5), 74.53 (C-8), 34.47 (C-9), 19.05 (C-10a), 18.20 (C-10b), 1.91 $\left({ }^{1}\left({ }^{119} \mathrm{Sn}^{-13} \mathrm{C}\right)=652 \mathrm{~Hz}, \mathrm{C}-1^{1}\right),-0.19\left({ }^{1} J\left({ }^{119} \mathrm{Sn}^{-13} \mathrm{C}\right)=638 \mathrm{~Hz}, \mathrm{C}-1^{1}\right)$. ${ }^{119}$ Sn NMR $\left(\mathrm{CDCl}_{3}, \delta\right):-157.6$.

\section{(S)-[3- $\left.\mathrm{CH}_{3} \mathrm{O}-2-\mathrm{OC}_{6} \mathrm{H}_{3} \mathrm{C}(\mathrm{H})=\mathrm{NCH}\left(\mathrm{CH}\left(\mathrm{CH}_{3}\right)_{2}\right) \mathrm{C}(\mathrm{O}) \mathrm{O}\right]$ $\mathrm{SnEt}_{2}(\mathbf{3})$}

Yield: $77 \%$ (0.49 g). M.p.: $196-197^{\circ} \mathrm{C} .[\alpha]_{\mathrm{D}}{ }^{23}(c=0.16$ $\left.\mathrm{g} \cdot \mathrm{mL}^{-1}, \mathrm{CH}_{2} \mathrm{Cl}_{2}\right)=-169.4^{\circ}$. Elemental analysis calcd for $\mathrm{C}_{17} \mathrm{H}_{25} \mathrm{NO}_{4} \mathrm{Sn}$ : C, 47.92; H, 5.91; N, 3.29\%. Found: C, 48.05; $\mathrm{H}, 5.87$; N, 3.27\%. IR ( $\mathrm{KBr}$ pellets, $\left.\mathrm{cm}^{-1}\right): 1653 \mathrm{v}(\mathrm{C}(\mathrm{O}) \mathrm{O})_{\text {asym, }}$, $1610 \mathrm{v}(\mathrm{C}=\mathrm{N}), 1360 \mathrm{v}(\mathrm{C}(\mathrm{O}) \mathrm{O})_{\mathrm{sym}} \cdot{ }^{1} \mathrm{H}$ NMR $\left(\mathrm{CDCl}_{3}, \delta\right): 1.06$ (d, 3H, H-10a), 1.09 (d, 3H, H-10b), 1.11 (t, 3H, H-2'), 1.32 (q, 2H, H-1'), 1.43 (t, 3H, H-2'), 1.74 (q, 2H, H-1'), 2.30-2.37 $(\mathrm{m}, 1 \mathrm{H}, \mathrm{H}-9), 3.84\left(\mathrm{~d},{ }^{3} \mathrm{~J}\left({ }^{119} \mathrm{Sn}^{-1} \mathrm{H}\right)=35 \mathrm{~Hz}, 1 \mathrm{H}, \mathrm{H}-8\right), 3.86$ (s, 3H, OCH $)_{3}, 6.71(\mathrm{t}, 1 \mathrm{H}, \mathrm{H}-5), 6.81(\mathrm{~d}, 1 \mathrm{H}, \mathrm{H}-4), 6.99(\mathrm{~d}, 1 \mathrm{H}$, $\mathrm{H}-6), 8.25\left(\mathrm{~s},{ }^{3} \mathrm{~J}\left({ }^{119} \mathrm{Sn}^{-1} \mathrm{H}\right)=48 \mathrm{~Hz}, 1 \mathrm{H}, \mathrm{H}-7\right) .{ }^{13} \mathrm{CNMR}\left(\mathrm{CDCl}_{3}, \delta\right)$ : 173.17 (C-11), 173.05 (C-7), 159.16 (C-2), 151.77 (C-3), 126.21, 117.38, 117.05, 116.89 (Ar-C), 74.53 (C-8), $56.18\left(\mathrm{OCH}_{3}\right), 34.46$ (C-9), 18.97 (C-10a), 18.28 (C-10b), $14.46\left({ }^{1} J\left({ }^{119} \mathrm{Sn}^{-13} \mathrm{C}\right)=590\right.$ $\left.\left.\mathrm{Hz}, \mathrm{C}-1^{\prime}\right), 14.12\left({ }^{1} \mathrm{~J}^{119} \mathrm{Sn}^{-13} \mathrm{C}\right)=580 \mathrm{~Hz}, \mathrm{C}-1^{1}\right), 9.74\left(\mathrm{C}-2^{1}\right), 9.34$ $\left(\mathrm{C}-2^{\prime}\right) .{ }^{119} \mathrm{Sn} \mathrm{NMR}\left(\mathrm{CDCl}_{3}, \delta\right):-184.7$.

$(S)-\left(3,5-\mathrm{Br}_{2}-2-\mathrm{OC}_{6} \mathrm{H}_{2} \mathrm{C}(\mathrm{H})=\mathrm{NCH}\left(\mathrm{CH}\left(\mathrm{CH}_{3}\right)_{2}\right) \mathrm{C}(\mathrm{O}) \mathrm{O}\right) \mathrm{Sn}(\mathrm{Bu}-n)_{2}$ (4).

Yield: $85 \%\left(0.76\right.$ g). M.p. $158-159^{\circ} \mathrm{C} .[\alpha]_{\mathrm{D}}{ }^{23}(c=0.09$ $\left.\mathrm{g} \cdot \mathrm{mL}^{-1}, \mathrm{CH}_{2} \mathrm{Cl}_{2}\right)=-197.5^{\circ}$. Elemental analysis calcd for $\mathrm{C}_{20} \mathrm{H}_{29} \mathrm{Br}_{2} \mathrm{NO}_{3} \mathrm{Sn}$ : C, 39.38; H, 4.79; N, 2.30\%. Found: C, 39.23; $\mathrm{H}, 4.56 ; \mathrm{N}, 2.22 \%$. (KBr pellets, $\left.\mathrm{cm}^{-1}\right): 1672 \mathrm{v}(\mathrm{C}(\mathrm{O}) \mathrm{O})_{\text {asym }}, 1609$ $v(\mathrm{C}=\mathrm{N}), 1345 \mathrm{v}(\mathrm{C}(\mathrm{O}) \mathrm{O})_{\text {sym }} .{ }^{1} \mathrm{H}$ NMR $\left(\mathrm{CDCl}_{3}, \delta\right): 0.83(\mathrm{t}, 3 \mathrm{H}$, H-4'), 0.97 (t, 3H, H-4'), 1.05 (d, 3H, H-10a), 1.09 (d, 3H, $\mathrm{H}-10 \mathrm{~b}), 1.25-1.85$ (m, 12H, H-1', H-2', and H-3'), 2.30-2.36 (m, 1H, H-9), $\left.3.88\left(\mathrm{~d},{ }^{3} \mathrm{~J}^{119} \mathrm{Sn}^{-1} \mathrm{H}\right)=35 \mathrm{~Hz}, 1 \mathrm{H}, \mathrm{H}-8\right), 7.34$ (d, $1 \mathrm{H}, \mathrm{H}-6), 7.85$ (d, $1 \mathrm{H}, \mathrm{H}-4), 8.22\left(\mathrm{~s},{ }^{3} \mathrm{~J}^{(119} \mathrm{Sn}^{-1} \mathrm{H}\right)=44 \mathrm{~Hz}$, 1H, H-7). ${ }^{13} \mathrm{C} \mathrm{NMR}\left(\mathrm{CDCl}_{3}, \delta\right): 173.24$ (C-11), 170.89 (C-7), 163.63 (C-2), 141.87 (C-4), 135.98 (C-6), 118.24 (C-1), 118.09 (C-3), 107.47 (C-5), 74.60 (C-8), 34.19 (C-9), 18.98 (C-10a), 18.16 (C-10b), 26.94 (C-2'), 26.71 (C-2'), 26.67 (C-3'), 26.56 (C-3'), $22.57\left({ }^{1} J\left({ }^{119} \mathrm{Sn}^{-13} \mathrm{C}\right)=600 \mathrm{~Hz}, \mathrm{C}-1^{1}\right), 22.19\left({ }^{1} J\left({ }^{119} \mathrm{Sn}^{-13} \mathrm{C}\right)=594 \mathrm{~Hz}\right.$, C-1'), 13.65 (C-4'), 13.51 (C-4'). ${ }^{119} \mathrm{Sn}$ NMR $\left(\mathrm{CDCl}_{3}, \delta\right):-196.2$.

(S)- $\left(3-\left(\mathrm{CH}_{3} \mathrm{O}\right)_{2} \mathrm{CH}-5-\mathrm{CH}_{3}-2-\mathrm{OC}_{6} \mathrm{H}_{2} \mathrm{C}(\mathrm{H})=\mathrm{NCH}\left(\mathrm{CH}\left(\mathrm{CH}_{3}\right)_{2}\right) \mathrm{C}(\mathrm{O})\right.$ O) $\mathrm{Sn}(\mathrm{Bu}-n)_{2}(5)$

Yield: $69 \%$ (0.56 g). M.p.: $131-132^{\circ} \mathrm{C} .[\alpha]_{\mathrm{D}}^{23}(c=0.12$ $\left.\mathrm{g} \cdot \mathrm{mL}^{-1}, \mathrm{CH}_{2} \mathrm{Cl}_{2}\right)=-201.4^{\circ}$. Elemental analysis calcd for $\mathrm{C}_{24} \mathrm{H}_{39} \mathrm{NO}_{5} \mathrm{Sn}$ : C, 53.35; H, 7.28; N, 2.59\%. Found: C, 53.16; 
$\mathrm{H}, 7.17$; N, 2.44\%. IR ( $\mathrm{KBr}$ pellets, $\left.\mathrm{cm}^{-1}\right): 1656 \mathrm{v}(\mathrm{C}(\mathrm{O}) \mathrm{O})_{\text {asym, }}$, $1614 \mathrm{v}(\mathrm{C}=\mathrm{N}), 1344 \mathrm{v}(\mathrm{C}(\mathrm{O}) \mathrm{O})_{\mathrm{sym}} \cdot{ }^{1} \mathrm{H} \mathrm{NMR}\left(\mathrm{CDCl}_{3}, \delta\right): 0.80$ (t, 3H, H-4'), 0.97 (t, 3H, H-4'), 1.05 (d, 3H, H-10b), 1.09 (d, 3H, H-10b), 1.24-1.29 (m, 4H, H-3'), 1.41-1.48 (m, 4H, H-2'), 1.65-1.70 (m, 2H, H-1'), 1.78-1.83 (m, 2H, H-1'), 2.27 (s, 3H, $\mathrm{ArCH}_{3}$ ), 2.31-2.34 (m, 1H,CH-9), 3.36 (s, 3H, $\left.\mathrm{CH}_{3} \mathrm{O}\right)$, $\left.3.44\left(\mathrm{~s}, 3 \mathrm{H}, \mathrm{CH}_{3} \mathrm{O}\right), 3.82\left(\mathrm{~d},{ }^{3} \mathrm{~J}^{(119} \mathrm{Sn}^{-1} \mathrm{H}\right)=35 \mathrm{~Hz}, 1 \mathrm{H}, \mathrm{H}-8\right)$, 5.60 (s, $\left.1 \mathrm{H}, \mathrm{CHO}_{2}\right), 6.97$ (d, 1H, H-6), 7.54 (d, 1H, H-4), $8.19\left(\mathrm{~s},{ }^{3} \mathrm{~J}\left({ }^{119} \mathrm{Sn}^{-1} \mathrm{H}\right)=48 \mathrm{~Hz}, 1 \mathrm{H}, \mathrm{H}-7\right) .{ }^{13} \mathrm{C} \mathrm{NMR}\left(\mathrm{CDCl}_{3}, \delta\right)$ : 173.19 (C-11), 172.25 (C-7), 165.31 (C-2), 136.68 (C-3), 135.23 (C-4), 130.26 (C-5), 125.98 (C-6), 116.97 (C-1), $99.41\left(\mathrm{CHO}_{2}\right.$ ), 74.64 (C-8), $54.87\left(\mathrm{CH}_{3} \mathrm{O}\right), 53.88\left(\mathrm{CH}_{3} \mathrm{O}\right), 34.53$ (C-9), 19.08 (C-10a), 18.38 (C-10b), 27.04 (C-2'), 26.83 (C-2'), 26.82 (C-3'),

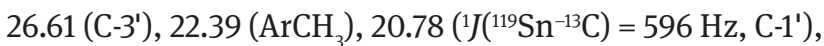
$\left.20.19\left({ }^{1}{ }^{(119} \mathrm{Sn}^{-13} \mathrm{C}\right)=588 \mathrm{~Hz}, \mathrm{C}-1^{1}\right), 13.68\left(\mathrm{C}-4^{\prime}\right), 13.43\left(\mathrm{C}-4^{\prime}\right)$. ${ }^{119} \mathrm{Sn}$ NMR $\left(\mathrm{CDCl}_{3}, \delta\right):-196.8$.

\section{X-ray crystallography}

The yellow crystals of 1-5 suitable for X-ray investigation were obtained from the dichloromethane-methanol solution of respective complex by slow evaporation. The intensity data for 1-5 were collected at 295(2) K on a Bruker Smart Apex area-detector fitted with graphite

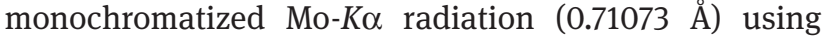
an $\omega-\varphi$ scan mode. The structures were solved by direct methods using SHELXS-97 (Sheldrick, 2008) and refined by a full-matrix least squares procedure based on $F^{2}$ using the SHELXL2014 program (Sheldrick, 2015). The non-hydrogen atoms were refined anisotropically and hydrogen atoms were placed at calculated positions in the riding model approximation. For compound 1, the residual electron density was difficult to model and therefore, the SQUEEZE routine in PLATON (Spek, 2015) was used to remove the contribution of the electron density in the solvent region from the intensity data and the solvent-free model was employed for the final refinement. The solvent formula mass was not taken into account during refinement. In the unit cell, the six major_platon_squeeze_void_volume add up to $1127 \AA^{3}$ and electrons of 299, and they roughly match 15 water and 9 methanol molecules according to the solvent of crystallization. The details (SQUEEZE RESULTS) were documented in the CIF. In addition, one reflection ( $\left.\begin{array}{lll}0 & 1 & 5\end{array}\right)$ with intensities seriously effected by the beamstop was omitted during the refinement. In compounds $\mathbf{4}$ and $\mathbf{5}$, the $n$-butyl groups attached to $\mathrm{Sn}(1)$ were refined by using DFIX, SIMU and DELU instructions. Crystallographic data and refinement details for 1-5 are listed in Table 3.

Table 3: Crystallographic and refinement data for 1-5.

\begin{tabular}{|c|c|c|c|c|c|}
\hline Compound & 1 & 2 & $3 \cdot \mathrm{H}_{2} \mathrm{O}$ & 4 & 5 \\
\hline Empirical formula & $\mathrm{C}_{42} \mathrm{H}_{57} \mathrm{~N}_{3} \mathrm{O}_{9} \mathrm{Sn}_{3}$ & $\mathrm{C}_{14} \mathrm{H}_{18} \mathrm{BrNO}_{3} \mathrm{Sn}$ & $\mathrm{C}_{17} \mathrm{H}_{27} \mathrm{NO}_{5} \mathrm{Sn}$ & $\mathrm{C}_{20} \mathrm{H}_{29} \mathrm{Br}_{2} \mathrm{NO}_{3} \mathrm{Sn}$ & $\mathrm{C}_{24} \mathrm{H}_{39} \mathrm{NO}_{5} \mathrm{Sn}$ \\
\hline Formula weight & 1104.04 & 446.89 & 444.08 & 609.95 & 540.25 \\
\hline Crystal system & Trigonal & Orthorhombic & Orthorhombic & Orthorhombic & Orthorhombic \\
\hline Space group & $R 3_{2}$ & $P 2_{1} 2_{1} 2_{1}$ & $P 2_{1} 2_{1} 2_{1}$ & $P 2_{1} 2_{1} 2_{1}$ & $P 2_{1} 2_{1} 2_{1}$ \\
\hline$a / \AA$ & $14.5569(17)$ & $8.8660(8)$ & 8.0192(9) & $8.7336(14)$ & $8.9482(13)$ \\
\hline$b / \AA$ & $14.5569(17)$ & 10.4392(9) & $14.6874(16)$ & $10.8022(18)$ & $9.1865(13)$ \\
\hline$c / \AA$ & 41.380(5) & $18.1992(16)$ & $16.4396(18)$ & $25.210(4)$ & $31.396(5)$ \\
\hline$\alpha /\left(^{\circ}\right)$ & 90 & 90 & 90 & 90 & 90 \\
\hline$\beta /\left(^{\circ}\right)$ & 90 & 90 & 90 & 90 & 90 \\
\hline$\gamma /\left(^{\circ}\right)$ & 120 & 90 & 90 & 90 & 90 \\
\hline Volume $/ \AA^{3}$ & $7594(2)$ & 1684.4(3) & $1936.3(4)$ & $2378.4(7)$ & $2580.9(6)$ \\
\hline$Z$ & 6 & 4 & 4 & 4 & 4 \\
\hline$D_{\mathrm{c}} /\left(\mathrm{g} \cdot \mathrm{cm}^{-3}\right)$ & 1.448 & 1.762 & 1.523 & 1.703 & 1.390 \\
\hline$\mu / \mathrm{mm}^{-1}$ & 1.517 & 3.894 & 1.344 & 4.453 & 1.022 \\
\hline$F(000)$ & 3312 & 872 & 904 & 1200 & 1120 \\
\hline$\theta$ range $/\left(^{\circ}\right)$ & $1.7-25.5$ & $2.2-26.0$ & $1.9-26.0$ & $1.6-25.5$ & $2.3-25.5$ \\
\hline Crystal size / mm & $0.22 \times 0.20 \times 0.20$ & $0.34 \times 0.30 \times 0.18$ & $0.16 \times 0.14 \times 0.04$ & $0.25 \times 0.18 \times 0.14$ & $0.60 \times 0.50 \times 0.18$ \\
\hline Tot. reflections & 15710 & 14613 & 15045 & 17732 & 15833 \\
\hline Uniq. reflections, $R_{\mathrm{int}}$ & $3172,0.031$ & $3293,0.033$ & $3802,0.027$ & $4422,0.048$ & $4800,0.026$ \\
\hline GOF on $F^{2}$ & 1.05 & 1.04 & 1.05 & 1.03 & 1.08 \\
\hline$R_{1}$ indices $[I>2 \mathrm{~s} \sigma(I)]$ & 0.027 & 0.026 & 0.024 & 0.049 & 0.040 \\
\hline$w R_{2}$ indices (all data) & 0.068 & 0.063 & 0.059 & 0.119 & 0.109 \\
\hline Flack parameter & $-0.023(15)$ & $0.030(11)$ & $-0.021(11)$ & $0.018(10)$ & $-0.013(12)$ \\
\hline$\Delta \rho_{\min }, \Delta \rho_{\max } /\left(\mathrm{e} \cdot \AA^{-3}\right)$ & $-0.437,0.409$ & $-0.349,0.549$ & $-0.209,0.476$ & $-0.772,1.134$ & $-0.453,0.986$ \\
\hline
\end{tabular}


Crystallographic information of 1-5 has been deposited with the Cambridge Crystallographic Data Centre, and the CCDC numbers are 1975365-1975369.

Acknowledgements: The financial support of the Undergraduate Research and Training Project of Qufu Normal University (No. 2018A045) and the National Natural Science Foundation of China (No. 21702119) are gratefully acknowledged.

\section{References}

Addison A.W., Rao T.N. , Reedijk J., van Rijn J. , Verschoor, G.C., Synthesis, structure, and spectroscopic properties of copper compounds containing nitrogen-sulphur donor ligands: the crystal and molecular structure of aqua[l,7-bis $(\mathrm{N}$-methylbenzimidazol-2'-yl)-2,6-dithiaheptane]copper perchlorate. J. Chem. Soc. Dalton, 1984, 1349-1356, DOI:10.1039/DT9840001349.

Arjmand F., Parveen S., Tabassum S., Pettinari C., Organotin antitumor compounds: their present status in drug development and future perspectives. Inorg. Chim. Acta, 2014, 423, 26-37, DOI:10.1016/j.ica.2014.07.066.

Banti C.N., Hadjikakou S.K., Sismanoglu T., Hadjiliadis N., Anti-proliferative and antitumor activity of organotin(IV) compounds. An overview of the last decade and future perspectives. J. Inorg. Biochem., 2019, 194, 114-152, DOI:10.1016/j.jinorgbio.2019.02.003.

Baul T.S.B., Kehie P., Duthie A., Höpfl H., Synthesis, characterization, crystal structures and supramolecular features of bicycloazas. tannoxides derived from Schiff bases with L-tyrosine. J. Organomet. Chem., 2017, 828, 96-105, DOI:10.1016/j. jorganchem.2016.11.028.

Baul T.S.B., Masharing C., Willem R., Biesemans M., Holcapek M., Jirasko R., et al., Self-assembly of diorganotin(IV) 2-\{[(E)-1-(2oxyaryl)alkylidene]amino\}acetates: An investigation of structures by X-ray diffraction, solution and solid-state tin NMR, and electrospray ionization MS. J. Organomet. Chem., 2005, 690, 3080-3094, DOI:10.1016/j.jorganchem.2005.03.010.

Belokon Y. N., Maleev V. I., Kataev D. A., Saveleva T. F., North M., Chiral ion pairs in catalysis: lithium salts of chiral metallocomplex anions as catalysts for asymmetric $\mathrm{C}-\mathrm{C}$ bond formation. Tetrahedron-Asymmetr., 2009, 20, 1746-1752, DOI:10.1016/j. tetasy.2009.06.006.

Beltran H.I., Zamudio-Rivera L.S., Mancilla T., Santillan R., Farfan N., One-step preparation, structural assignment, and X-ray study of 2,2-di-nbutyl-and 2,2-diphenyl-6-aza-1,3-dioxa-2-stannabenzocyclononen-4-ones derived from amino acids. Chem. Eur. J., 2003, 9, 2291-2306, DOI:10.1002/chem.200204260.

Chen C.-T., Bettigeri S., Weng S.-S., Pawar V.D., Lin Y.-H., Liu C.-Y., et al., Asymmetric aerobic oxidation of $\alpha$-hydroxy acid derivatives by C4-symmetric, vanadate-centered, tetrakisvanadyl(V) clusters derived from $\mathrm{N}$-salicylidene- $\alpha$-aminocarboxylates. J. Org. Chem., 2007, 72, 8175-8185, DOI:10.1021/j0070575f.

Chen C.-T., Lin J.-S., Kuo J.-H., Weng S.-S., Cuo T.-S., Lin Y.-W., et al., Site-selective DNA photocleavage involving unusual photoinitiated tautomerization of chiral tridentate vanadyl $(\mathrm{V})$ complexes derived from $\mathrm{N}$-salicylidene $\alpha$-amino acids. Org. Lett., 2004, 6, 4471-4474, DOI:10.1021/ol048156h.

Davies A.G., Gielen M., Pannell K.H., Tiekink E.R.T., Tin Chemistry: Fundamentals, Frontiers, and Applications. John Wiley \& Sons, Chichester, U.K., 2008, DOI:10.1002/9780470758090.

Deacon G.B., Phillips R.J., Relationships between the carbon-oxygen stretching frequencies of carboxylato complexes and the type of carboxylate coordination. Coord. Chem. Rev., 1980, 33, 227-250, DOI: 10.1016/S0010-8545(00)80455-5.

Degaonkar M.P., Puranik V.G., Tavale S.S., Gopinathan S., Gopinathan C., Synthesis and spectroscopic investigations of some binuclear organotin(IV) complexes of malonobis(salicy lidenehydrazide). Bull. Chem. Soc. Jpn., 1994, 67, 1797-1801, DOI:10.1246/bcsj.67.1797.

Eng G., Review: Quantitative structure-activity/property relationships as related to organotin chemistry. Appl. Organomet. Chem., 2017, 31, e3712, DOI:10.1002/aoc.3712.

Flack H.D., On enantiomorph-polarity estimation. Acta Cryst., 1983, A39, 876-881, DOI:10.1107/S0108767383001762.

Holecek J., Nadvornik M., Handlir K., ${ }^{13} \mathrm{C}$ and ${ }^{119} \mathrm{Sn}$ NMR spectra of dibutyltin(IV) compounds. J. Organomet. Chem., 1986, 315, 299-308, DOI:10.1016/0022-328X(86)80450-8.

Liu J., Lin Y., Liu M., Wang S., Li Y., Liu X., et al., Synthesis, structural characterization and cytotoxic activity of triorganotin 5-(salicylideneamino)salicylates. Appl. Organometal. Chem., 2019, 33, e4715, DOI:10.1002/aoc.4715.

Liu Q., Zhang H., Zheng X., Wang W., Tian L., Synthesis, structure and cytotoxic activity of diethyltin $\mathrm{N}$-[(2-oxyphenyl)methylene] phenylalaninates. Appl. Organometal. Chem., 2016, 30, 630-637, DOI:10.1002/aoc.3480.

Lockhart T.P., Manders W.F., Solid-state carbon-13 NMR investigation of methyltin(IV) compounds. Correlation of NMR parameters with molecular structure. J. Am. Chem. Soc., 1987, 109, 7015-7020, DOI:10.1021/ja00257a018.

Rivera J.M., Reyes H., Cortes A., Santillan R., Second-harmonic generation within the $P 22_{1}{ }_{1}{ }_{1}$ space group, in a series of chiral (salicylaldiminato)tin Schiff base complexes. Chem. Mater., 2006, 18, 1174-1183, DOI:10.1021/cm051589+.

Sheldrick G.M., A short history of SHELX. Acta Crystallogr., 2008, A64, 112-122, DOI:10.1107/S0108767307043930.

Sheldrick G.M., SHELXL-Integrated space-group and crystal-structure determination. Acta Crystallogr., 2015, A71, 3-8, DOI:10.1107/ S2053273314026370.

Singh N., Kumar K., Srivastav N., Singh R., Kaur V., Jasinski J.P., et al., Exploration of fluorescent organotin compounds of a-amino acid Schiff bases for the detection of organophosphorous chemical warfare agents:quantification of diethylchlorophosphate. New J. Chem., 2018, 42, 8756-8764, DOI:10.1039/c8nj01153b.

Spek, A.L., PLATON SQUEEZE: a tool for the calculation of the disordered solvent contribution to the calculated structure factors. Acta Crystallogr., 2015, C71, 9-18, DOI:10.1107/ S2053229614024929.

Tian L., Qian B., Sun Y., Zheng X., Yang M., Li H., et al., Synthesis, structural characterization and cytotoxic activity of diorganotin complexes of $\mathrm{N}$-(5-halosalicylidene)- $\alpha$-amino acid. Appl. Organomet. Chem., 2005, 19, 980-987, DOI:10.1002/aoc.940.

Tian L., Yao Y., Wang Y., Liu J., Synthesis, structure and property of diorganotin complexes with chiral $\mathrm{N}$-(5-chlorosalicylidene) valinate ligand. J. Mol. Struct., 2018, 1156, 441-449, DOI:10.1016/j.molstruc.2017.11.132. 
Tian L.-J., Chen L.-X., An W.-G., Liu X.-C., Diorganotin complexes of $N$-[4-(diethylamino)salicylidene]-(L)-tryptophane: syntheses, structures and properties. Chinese J. Struct. Chem., 2019, 38, 1977-1985, DOI:10.14102/j.cnki.0254-5861.2011-2378.

Tian L.-J., Sun Y.-X., Zheng X.-L., Liu X.-J., Yu Y., Liu X.-L., et al., Synthesis, Characterization and biological activity of diorganotin(IV) complexes of N-(3,5-dibromosalicylidene)- $\alpha$-amino acid. Chin. J. Chem., 2007, 25, 312-318, DOI:10.1002/cjoc.200790061.

Tian L.-J., Yao Y.-Z., Liu Q.-T., Zheng X.-F., Synthesis, characterization and antibacterial activity of cyclohexyltin complexes of $\mathrm{N}$-(3,5-dibromosalicylidene)valine. Chin. J. Struct. Chem., 2016, 35, 849-856, DOI:10.14102/j.cnki.0254-5861.2011-1058.

Ucar A., Findik M., Bingol H., Guler E., Ozcan E., Organometallic chiral Schiff base for enantio-selective fluorescent recognition of methionine. Chem. Pap., 2017, 71, 1855-1862, DOI:10.1007/ s11696-017-0179-7.

Yao Y., Yang M., Zheng X., Tian L., Synthesis, characterization, and cytotoxic activity of triphenyltin complexes of $N$-(5-bromosalicylidene)- $\alpha$-amino acids. Main Group Met. Chem., 2017, 40, 93-99, DOI:10.1515/mgmc-2017-0015.

Yin H.-D., Wang Q.-B., Xue S.-C., Synthesis and structural characterization of diorganotin esters of salicylidene-amino acids. J. Organomet. Chem., 2004, 689, 2480-2485, DOI:10.1016/j. jorganchem.2004.05.004.

Yu J., Jiang H.-J., Zhou Y., Luo S.-W., Gong L.-Z., Sodium salts of anionic chiral cobalt(III) complexes as catalysts of the enantioselective Povarov reaction. Angew. Chem. Int. Ed., 2015, 54, 11209-11213, DOI:10.1002/anie.201504790. 